\title{
Antiproliferative Activity of Cardenolides Isolated from Streptocaulon juventas
}

\author{
Jun-ya Ueda, ${ }^{a}$ Yasuhiro Tezuka, ${ }^{a}$ Arjun Hari Banskota, ${ }^{a}$ Quan Le Tran, ${ }^{a}$ Qui Kim Tran,,${ }^{b}$ \\ Ikuo SAIKI, ${ }^{a}$ and Shigetoshi KADOTA ${ }^{*, a}$ \\ ${ }^{a}$ Institute of Natural Medicine, Toyama Medical and Pharmaceutical University; 2630 Sugitani, Toyama 930-0194, Japan: \\ and ${ }^{b}$ National University-Hochiminh City; Hochiminh City, Vietnam. Received May 21, 2003; accepted June 20, 2003
}

\begin{abstract}
Sixteen cardenolides, two hemiterpenoids, two phenylpropanoids and a phenylethanoid isolated from the roots of Streptocaulon juventas (LOUR.) MERR. were examined for their antiproliferative activity toward three human-derived (HT-1080 fibrosarcoma, lung A549 adenocarcinoma, cervix HeLa adenocarcinoma) and three murine-derived (colon 26-L5 carcinoma, Lewis lung carcinoma, B16-BL6 melanoma) cell lines. The cardenolides selectively and strongly inhibited proliferation of the HT-1080 (IC ${ }_{50}$ values, 0.054-1.6 $\left.\mu_{\mathrm{M}}\right)$ and $\mathrm{A549}\left(\mathrm{IC}_{50}\right.$, $0.016-0.65 \mu \mathrm{M})$ cell lines. The characteristic morphological changes and ladder-like DNA fragmentation in those cells treated with the cardenolides indicated the antiproliferative activity was due to the induction of apoptosis.
\end{abstract}

Key words antiproliferative activity; cardenolides; apoptosis; Streptocaulon juventas; human HT-1080 fibrosarcoma; human lung A549 adenocarcinoma

Streptocaulon juventas (Lour.) MerR. is a plant in the Asclepiadaceae family which is native in Indochina. This plant is called "Ha thu o trang," in Vietnam, ${ }^{1-3)}$ and its roots are used as tonic for anemia, chronic malaria, rheumatism, menstrual disorders, neurasthenia, and dyspepsia, as an equivalent of "Ha thu o do (roots of Polygonum multiflorum THunB., Polygonaceae)". In the course of our research on Vietnamese medicinal plants, ${ }^{4-7)}$ we found that the $\mathrm{MeOH}$ extract of roots of $S$. juventas strongly and selectively inhibited proliferation of the human HT-1080 fibrosarcoma cell line $\left(\mathrm{IC}_{50}\right.$ value, $\left.1.2 \mu \mathrm{g} / \mathrm{ml}){ }^{8}\right)$ Thus, the extract was partitioned into $\mathrm{Et}_{2} \mathrm{O}, \mathrm{AcOEt}, \mathrm{BuOH}$, and water fractions, among which the $\mathrm{AcOEt}$ and $\mathrm{BuOH}$ fractions showed more potent antiproliferative activity than the others $\left(\mathrm{IC}_{50}\right.$ : ether fraction, $5.3 \mu \mathrm{g} / \mathrm{ml}$; AcOEt fraction, $0.57 \mu \mathrm{g} / \mathrm{ml} ; \mathrm{BuOH}$ fraction, $0.19 \mu \mathrm{g} / \mathrm{ml}$; $\mathrm{H}_{2} \mathrm{O}$ fraction, $79 \mu \mathrm{g} / \mathrm{ml}$ ). An activity-guided separation of the AcOEt and $\mathrm{BuOH}$ fractions was then conducted and 16 cardenolides, including five new ones, were isolated together with two new hemiterpenoids, two known phenylpropanoids, and a known phenylethanoid. ${ }^{9)}$ Among them, cardenolides exhibited potent antiproliferative activity $\left(\mathrm{IC}_{50}, 54-1600\right.$ nM) in the HT-1080 fibrosarcoma cell line. $\left.{ }^{9}\right)$

Cardenolides were isolated from plants belonging to 15 families such as Apocynaceae, Scrophulariaceae, and Asclepiadaceae,${ }^{10-12}$ and have been used clinically as cardiotonic drugs. Cardenolides were also reported to have cytotoxicity toward tumor cells. ${ }^{13)}$

In this study, we examined the antiproliferative activities of the cardenolides in six cancer cell lines, including four highly metastatic cell lines, i.e., human HT-1080 fibrosarcoma, human cervix HeLa adenocarcinoma, human lung A549 adenocarcinoma, murine colon 26-L5 carcinoma, murine Lewis lung carcinoma (LLC), and murine B16-BL6 melanoma cell lines.

\section{MATERIALS AND METHODS}

Materials Acovenosigenin A digitoxoside (1), digitoxigenin gentiobioside (2), digitoxigenin 3-O-[O- $\beta$-glucopyranosyl-( $1 \rightarrow 6)-O$ - $\beta$-glucopyranosyl-( $1 \rightarrow 4)-3-O$-acetyl- $\beta$-digi- toxopyranoside] (3), digitoxigenin 3-O-[O- $\beta$-glucopyranosyl$(1 \rightarrow 6)-O-\beta$-glucopyranosyl-( $1 \rightarrow 4)-O$ - $\beta$-digitalopyranosyl$(1 \rightarrow 4)-\beta$-cymaropyranoside] (4), periplogenin $3-O-(4-O-\beta$ glucopyranosyl- $\beta$-digitalopyranoside) (5), (4R)-4-hydroxy-3(1-methylethyl)pentyl rutinoside (6), (R)-2-ethyl-3-methylbutyl rutinoside (7), acovenosigenin A (8), periplogenin 3-O$\beta$-digitoxoside (9), periplocymarin (10), periplogenin (11), digitoxigenin (12), digitoxigenin 3-O-[O- $\beta$-D-glucopyranosyl-( $1 \rightarrow 6)-O-\beta$-D-glucopyranosyl-( $(\rightarrow 4)-\beta$-D-digitoxopyranoside] (13), digitoxigenin sophoroside (14), echujin (15), periplogenin glucoside (16), corchorusoside C (17), subalpinoside (18), caffeic acid (19), 4,5-di- $O$-caffeoylquinic acid (20), and 2-phenylethyl rutinoside (21) were isolated from roots of Streptocaulon juventas (Lour.) Merr. (Asclepiadaceae) as described previously. ${ }^{9}$ Eagle's minimum essential (EME) and Roswell Park Memorial Institute (RPMI) 1640 media and Dulbecco's phosphate buffered saline (PBS) were purchased from Nissui Pharmaceutical Co., Ltd. (Tokyo, Japan). Dulbecco's modified Eagle's medium nutrient mixture Ham's F-12 (1:1) (DMEM/F-12) medium and heat-inactivated fetal calf serum (FCS) were obtained from Invitrogen Co., (Grand Island, NY, U.S.A.). Bovine serum albumin (BSA), penicillin G, and streptomycin sulfate were purchased from Sigma Chemical Co. (St. Louis, MO, U.S.A.). 3-(4,5-Dimethylthiazol-2-yl)-2,5-diphenyl-2H-tetrazolium bromide (MTT) and crystal violet were purchased from Aldrich Chemical Co., Inc. (Milwaukee, WI, U.S.A.) and Nacalai Tesque (Kyoto, Japan), respectively. Cell culture flasks and 6- and 96-well plates were from Corning Inc. (Corning, NY, U.S.A.). 5-Fluorouracil and doxorubicin hydrochloride were purchased from Tokyo Kasei Kogyo Co., Ltd. (Tokyo, Japan) and Kyowa Hakko Kogyo Co., Ltd. (Tokyo, Japan), respectively. Ribonuclease (RNase), TE buffer (10 mm Tris-HCl buffer, 1 mm EDTA, pH 8.0), loading buffer, agarose, and ethidium bromide were purchased from Wako Pure Chemical Industries, Ltd. (Osaka, Japan). The 100 base-pair ladder was obtained from Amersham Pharmacia Biotech, Inc. (Piscataway, NJ, U.S.A.). Other reagents were of the highest grade available.

Cells Human HT-1080 fibrosarcoma cell line (ATCC \# 
CCL-121) ${ }^{14)}$ was obtained from American Type Culture Collection (Rockville, MD, U.S.A.), while human cervix HeLa adenocarcinoma (RCB0007) ${ }^{15}$ and human lung A549 adenocarcinoma (RCB0098) ${ }^{16,17)}$ cell lines were purchased from Riken Cell Bank (Tsukuba, Japan). Murine colon 26-L5 carcinoma cell line was established by one of the authors (I. Saiki). ${ }^{18)}$ LLC cell line that originated spontaneously from murine lung ${ }^{19)}$ was kindly provided by Dr. K. Takeda (Juntendo University, Tokyo, Japan), while murine B16-BL6 melanoma cell line, obtained by an in vivo selection procedure for invasion, ${ }^{20}$ was generously provided by Dr. I. J. Fidler (M.D. Anderson Cancer Center, Houston, TX, U.S.A.).

The HT-1080, HeLa, A549, LLC, and B16-BL6 cell lines were maintained in EME medium supplemented with $10 \%$ FCS and $2 \mathrm{~mm} \mathrm{~L}-(+)$-glutamine and $\mathrm{pH}$-balanced with $10 \%$ sodium bicarbonate at $37^{\circ} \mathrm{C}$ under a humidified $5 \%$ carbon dioxide atmosphere. The 26-L5 cell line was maintained in RPMI 1640 medium containing the same supplement under the same conditions.

Antiproliferative Activity Viability of cells other than LLC in the presence or absence of experimental specimens was determined using the standard MTT assay ${ }^{21)}$ as described previously. ${ }^{8)}$ In brief, exponentially growing cells were harvested and $100-\mu 1$ medium with $2 \times 10^{3}$ cells suspended was plated into each well in a 96-well plate. After 24-h incubation at $37^{\circ} \mathrm{C}$ under a humidified $5 \%$ carbon dioxide atmosphere to allow cell attachment, the cells were treated with varying concentrations of test compounds in their appropriate medium $(100 \mu \mathrm{l})$ and incubated for $72 \mathrm{~h}$ under the same conditions. After $2 \mathrm{~h}$ of MTT $(0.4-0.5 \mathrm{mg} / \mathrm{ml}, 100 \mu \mathrm{l})$ exposure, the formazan formed was extracted with DMSO and measured spectrophotometrically at $550 \mathrm{~nm}$ with a PerkinElmer HTS-7000 Bio Assay Reader (Norwalk, CT, U.S.A.).

In the case of LLC cells, a standard crystal violet staining assay described in the literature was used. ${ }^{8)}$ In brief, exponentially growing cells were harvested and 100- $\mu$ l medium per well with $1 \times 10^{3}$ cells suspended was plated in a 96-well plate. After $24-\mathrm{h}$ incubation at $37^{\circ} \mathrm{C}$ under a humidified $5 \%$ carbon dioxide atmosphere, $100-\mu 1$ medium containing various concentrations of test specimen was added to each well and incubated for $72 \mathrm{~h}$ under the same conditions. After fixation with $25 \%$ glutaraldehyde solution $(20 \mu \mathrm{l})$, the cells were stained with $0.5 \%$ crystal violet in $20 \% \mathrm{MeOH}-\mathrm{H}_{2} \mathrm{O}$ for $60 \mathrm{~min}$. After gentle rinsing with water, the retained crystal violet was extracted with $30 \%$ acetic acid and measured spectrophotometrically at $590 \mathrm{~nm}$.

Each sample was dissolved in a little of DMSO, PBS was added, and the mixture was diluted with the medium; the final concentration of DMSO was less than $0.25 \%$. 5-Fluorouracil and doxorubicin were used as positive controls. Cellular viability and $\mathrm{IC}_{50}$ values were calculated from the mean values of data from four wells. Cellular viability $(\%)=[\mathrm{Abs}$ (test sample) $/$ Abs (control) $] \times 100$.

Observation of Morphological Changes Morphological changes were observed as described previously. ${ }^{8)}$ Briefly, exponentially growing HT-1080 or A549 cells were harvested and plated at $1 \times 10^{5}$ cells per well in a 6-well plate. After 12-h incubation in EME medium at $37^{\circ} \mathrm{C}$ under a humidified 5\% carbon dioxide atmosphere, the cells were treated without or with varying concentrations $(10-1000$ $\mathrm{nM})$ of test specimens for $24 \mathrm{~h}$ in serum free DMEM/F-12 medium supplemented with $0.1 \% \mathrm{BSA}, 100 \mathrm{IU} / \mathrm{ml}$ penicillin $\mathrm{G}$, and $80 \mathrm{IU} / \mathrm{ml}$ streptomycin and $\mathrm{pH}$-balanced with $10 \%$ sodium bicarbonate. At the end of incubation, the morphological changes of the cells were recorded by photomicrography using a phase contrast microscope (Olympus Optical Co., Ltd., Tokyo).

Detection of DNA Fragmentation DNA was isolated and detected by a procedure described previously. ${ }^{8)}$ Briefly, HT-1080 $\left(1 \times 10^{6}\right.$ cells $)$ or A549 $\left(3 \times 10^{6}\right.$ cells $)$ cells were preincubated in EME medium for $12 \mathrm{~h}$, and then cultured without or with various concentrations $(10-1000 \mathrm{nM})$ of test specimen in serum free DMEM/F-12 medium containing $0.1 \%$ BSA for $24 \mathrm{~h}$. At the end of the incubation, the cells were pelleted and lysed in $600 \mu \mathrm{l}$ of lysis buffer $(10 \mathrm{~mm}$ Tris- $\mathrm{HCl}$ buffer, $10 \mathrm{~mm}$ EDTA and $0.2 \%$ Triton $\mathrm{X}-100, \mathrm{pH}$ 7.5) for $10 \mathrm{~min}$ under ice cooling. After the lysate was centrifuged at $14000 \mathrm{rpm}$ for $10 \mathrm{~min}$, the supernatant was extracted with TE buffer-saturated phenol and CIAA solution (chloroform : isoamylalcohol $=24: 1$ ), successively. DNA in the aqueous layer $(500 \mu \mathrm{l})$ was precipitated with $3 \mathrm{M} \mathrm{NaCl}$ $(50 \mu \mathrm{l})$ and cold ethanol $(1000 \mu \mathrm{l})$ at $-20^{\circ} \mathrm{C}$ overnight. After being centrifuged at $14000 \mathrm{rpm}$ for $10 \mathrm{~min}$, the supernatant was removed and evaporated. The remaining DNA was dissolved in TE buffer, and RNA contamination was eliminated by incubation with RNase $(1 \mathrm{mg} / \mathrm{ml})$ at $37^{\circ} \mathrm{C}$ for $30 \mathrm{~min}$. Following the addition of loading buffer, fragmented DNA was electrophoresed on $1.5 \%$ agarose gel in TAE ( $40 \mathrm{~mm}$ Trisbase, $20 \mathrm{~mm}$ acetic acid, $1 \mathrm{~mm}$ EDTA) at $100 \mathrm{~V}$ for $50 \mathrm{~min}$ and visualized by ethidium bromide staining.

\section{RESULTS AND DISCUSSION}

Compounds isolated from the roots of $S$. juventas (Fig. 1) were examined for their antiproliferative activity in human HT-1080 fibrosarcoma, human cervix HeLa adenocarcinoma,

Table 1. Antiproliferative Activities of Constituents Isolated from Streptocaulon juventas in Human HT-1080 Fibrosarcoma, Human Lung A549 Adenocarcinoma, Human Cervix HeLa Adenocarcinoma, and Murine Colon 26L5 Adenocarcinoma Cell Lines

\begin{tabular}{|c|c|c|c|c|}
\hline \multirow{2}{*}{ Compound } & \multicolumn{4}{|c|}{$\mathrm{IC}_{50}(\mu \mathrm{M})$} \\
\hline & HT-1080 & A549 & $\mathrm{HeLa}$ & $26-\mathrm{L} 5$ \\
\hline 1 & 1.1 & 0.31 & $>100$ & $>100$ \\
\hline 2 & 1.6 & 0.65 & $>100$ & $>100$ \\
\hline 3 & 0.59 & 0.17 & $>100$ & $>100$ \\
\hline 4 & 0.22 & 0.091 & $>100$ & $>100$ \\
\hline 5 & 0.67 & 0.27 & $>100$ & $>100$ \\
\hline 8 & 1.2 & 0.39 & $>100$ & $>100$ \\
\hline 9 & 0.093 & 0.031 & $>100$ & 84 \\
\hline 10 & 0.096 & 0.026 & 89 & 71 \\
\hline 11 & 0.81 & 0.26 & $>100$ & 97 \\
\hline 12 & 1.5 & 0.53 & $>100$ & $>100$ \\
\hline 13 & 0.054 & 0.020 & 68 & 61 \\
\hline 14 & 0.46 & 0.16 & $>100$ & $>100$ \\
\hline 15 & 0.055 & 0.016 & 82 & 57 \\
\hline 16 & 0.16 & 0.040 & $>100$ & $>100$ \\
\hline 17 & 0.092 & 0.037 & $>100$ & 90 \\
\hline 18 & 0.18 & 0.080 & $>100$ & 54 \\
\hline 5-Fluorouracil & 3.7 & 2.9 & 0.75 & 0.21 \\
\hline Doxorubicin & 0.059 & 0.026 & 0.31 & 0.58 \\
\hline
\end{tabular}

All compounds were inactive $\left(\mathrm{IC}_{50}\right.$ values $\left.>100 \mu \mathrm{M}\right)$ in murine LLC and murine B16-BL6 melanoma cell lines. Compounds $6,7, \mathbf{1 9}-21$ showed no activity toward any cell line. 
human lung A549 adenocarcinoma, murine colon 26-L5 carcinoma, murine LLC, and murine B16-BL6 melanoma cell lines. Three are human (HT-1080, HeLa, A549) and the others are murine (26-L5, LLC, B16-BL6) tumor cell lines, while four (HT-1080, 26-L5, LLC, B16-BL6) are invasive and metastatic. The cardenolides $(\mathbf{1}-\mathbf{5}, \mathbf{8}-\mathbf{1 8})$ exhibited po- tent activity with selectivity against two human-derived cell lines, i.e., HT-1080 $\left(\mathrm{IC}_{50}, 0.054-1.6 \mu \mathrm{M}\right)$ and $\mathrm{A} 549\left(\mathrm{IC}_{50}\right.$, $0.016-0.65 \mu \mathrm{M})$ cell lines, and the activities of $\mathbf{1 3}\left(\mathrm{IC}_{50}\right.$ toward HT-1080 and A549, 0.054 and $0.020 \mu \mathrm{M}$, respectively) and $15\left(\mathrm{IC}_{50}, 0.055\right.$ and $0.016 \mu \mathrm{M}$, respectively) were identical with those of doxorubicin $\left(\mathrm{IC}_{50}, 0.059\right.$ and $0.026 \mu \mathrm{M}$, re-

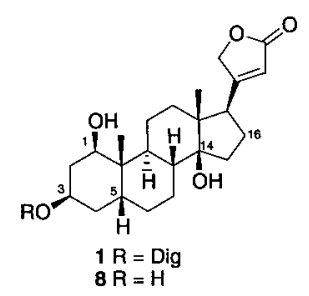

$\int_{6}^{\mathrm{H} / \mathrm{O}_{\mathrm{Glc}}^{6}-\mathrm{Rha}}$<smiles>CCC(CO[14CH3])C(C)C(C)(C)C</smiles>

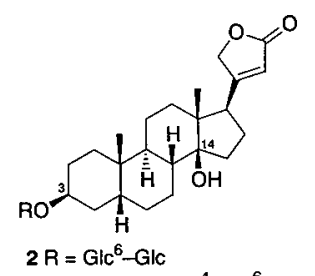

$3 R=(3-O-A C-D i g)^{4}-G \mid c^{6}-G l c$ $4 \mathrm{R}=\mathrm{Cym}^{4}-\mathrm{Dt} \mathrm{t}^{4}-\mathrm{Glc} \mathrm{c}^{6}-\mathrm{Glc}$ $12 \mathrm{R}=\mathrm{H}$

$13 \mathrm{R}=\mathrm{Dig}^{4}-\mathrm{Glc}^{6}-\mathrm{GlC}$

$14 \mathrm{R}=\mathrm{Glc}^{2}-\mathrm{Glc}$

$15 R=C y m^{4}-G\left|c^{6}-G\right| c$

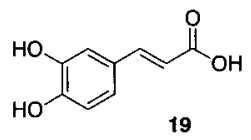

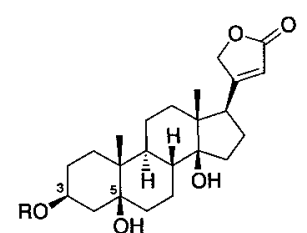

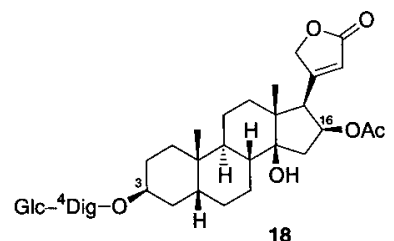

$5 \mathrm{R}=\mathrm{Dtt} \mathrm{t}^{4}-\mathrm{GlC}$ $9 \mathrm{R}=\mathrm{Dig}$ $10 \mathrm{R}=\mathrm{Cym}$

$11 \mathrm{R}=\mathrm{H}$

$16 \mathrm{R}=\mathrm{GlC}$

$17 \mathrm{R}=\mathrm{Dig}^{4}-\mathrm{GlC}$

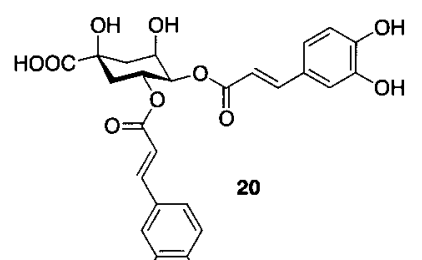

$\overbrace{21}^{O_{-G l c}-R h a}$

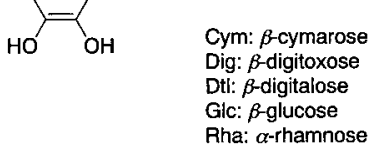

Fig. 1. Chemical Structure of Constituents of the Roots of Streptocaulon juventas
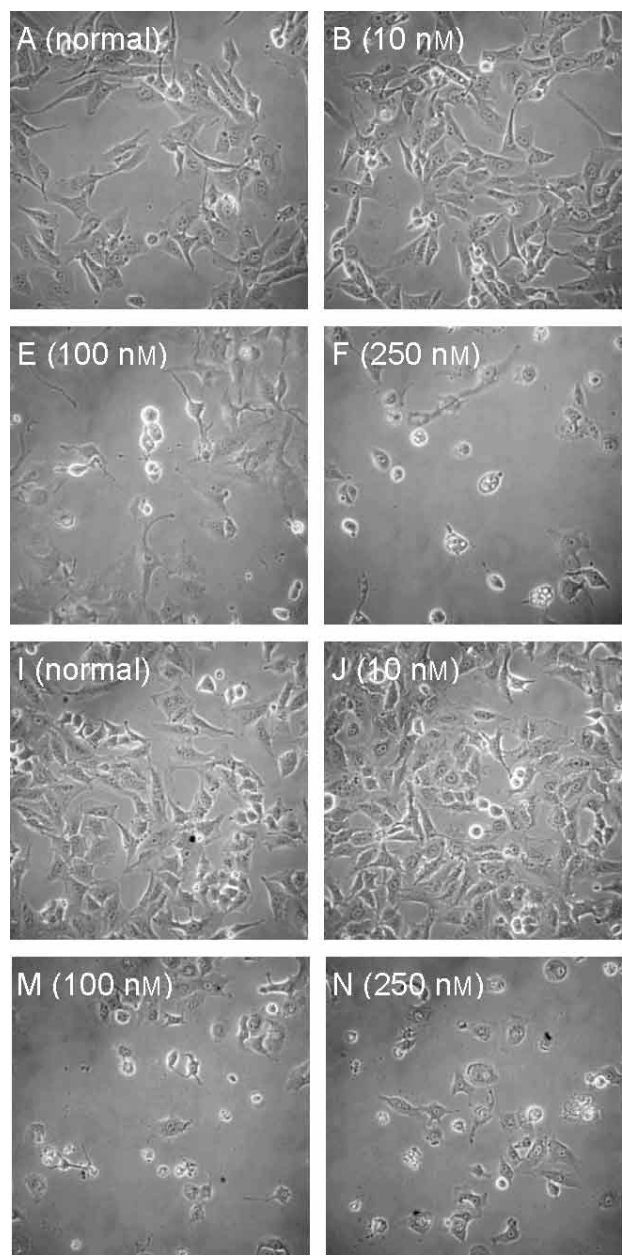
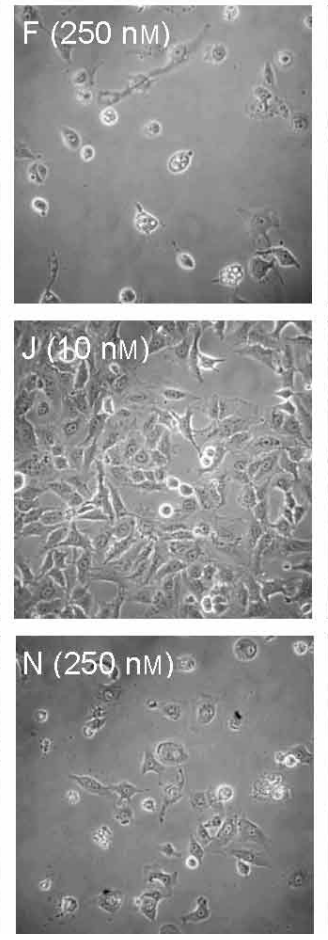
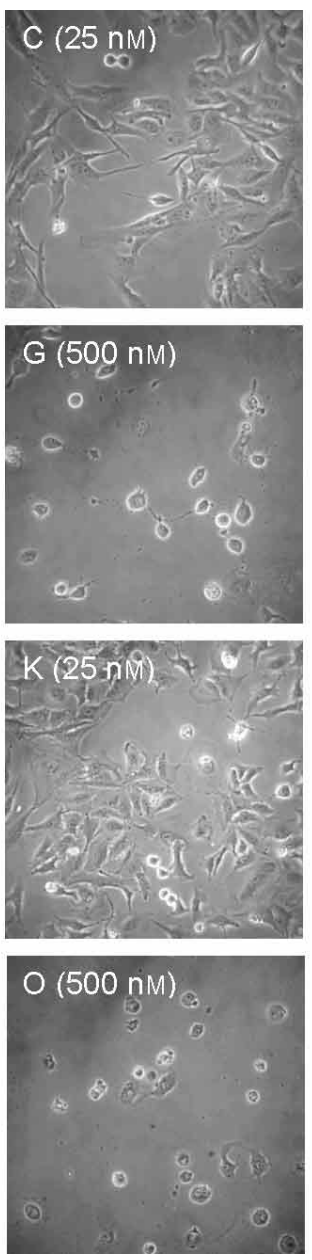
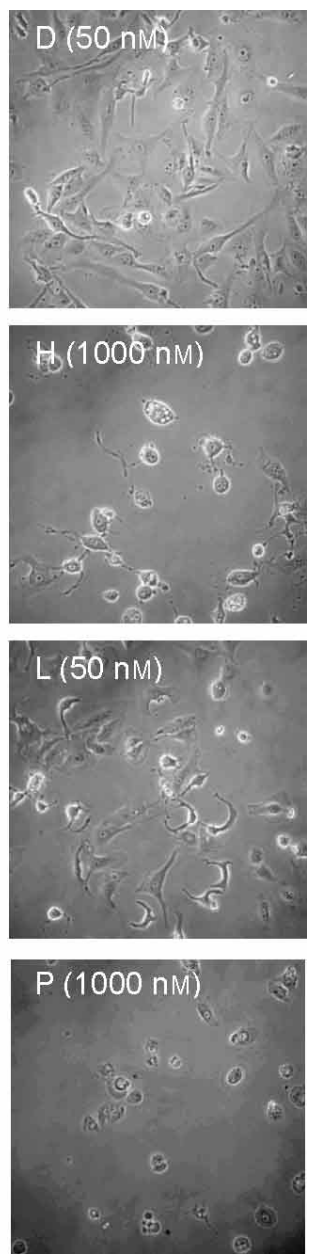

Fig. 2. Morphological Changes in Human HT-1080 Fibrosarcoma $(\mathrm{A}-\mathrm{H})$ and Human Lung A549 Adenocarcinoma (I—P) Cells by Treatment with Echujin (15)

After 12-h preincubation, the cells were cultured for $24 \mathrm{~h}$ in DMEM/F-12 medium without or with $10-1000 \mathrm{~nm}$ of 15 
A

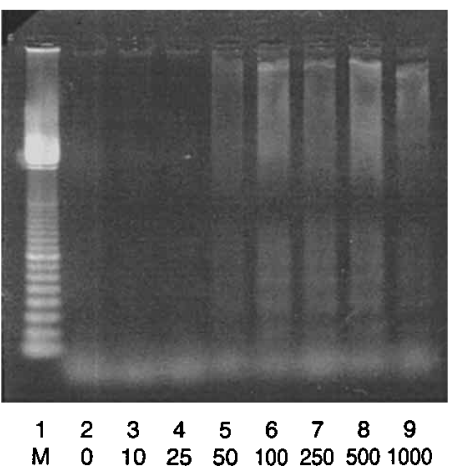

B

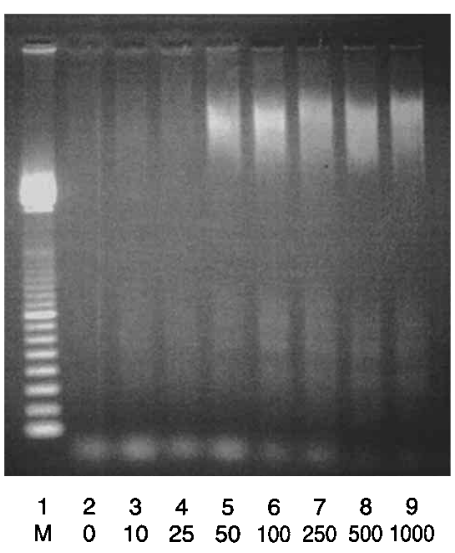

Fig. 3. DNA Fragmentation Induced by Echujin (15) in Human HT-1080 Fibrosarcoma (A) and Human Lung A549 Adenocarcinoma (B) Cells

After the cells were cultured for $24 \mathrm{~h}$ without or with various concentrations of $\mathbf{1 5}$, the fragmented DNA was isolated, electrophoresed on $1.5 \%$ agarose gel, and then visualized by ethidium bromide staining. Lane 1: 100 base-pair ladder marker; lane 2: normal; lanes 3-9: treated with $10,25,50,100,250,500$ and $1000 \mathrm{~nm}$ of $\mathbf{1 5}$, respectively.

spectively) (Table 1). Compounds other than the cardenolides $(6,7,19-21)$ showed no activity $\left(\mathrm{IC}_{50},>100 \mu \mathrm{M}\right)$ against any cell line.

In the structure-activity relationship of the cardenolides, digitoxigenin (12), the simplest cardenolide with only $3 \beta, 14 \beta$-dihydroxyl functionality, showed weaker activity than 8 and 11. The hydroxyl group at C-1 or C-5 of the aglycon part increased their activity, and the hydroxyl group at $\mathrm{C}$ 5 was more favorable $(\mathbf{1 2}<\mathbf{8}<\mathbf{1 1} ; \mathbf{1}<\mathbf{9}, \mathbf{1 0}, \mathbf{1 6})$, while the acetoxyl group at $\mathrm{C}-16$ made no difference. With respect to the number of sugars on the 3-hydroxyl group, monoglycosylation would intensify its activity $(\mathbf{8}<\mathbf{1} ; \mathbf{1 1}<\mathbf{9}, \mathbf{1 0}, \mathbf{1 6})$, however, diglycosylation would not intensify $(\mathbf{9}, \mathbf{1 0} \approx \mathbf{1 7})$ or would weaken the activity $(\mathbf{5}<\mathbf{9}, \mathbf{1 0}, \mathbf{1 6})$. Cardenolide trisaccharides 13 and 15 exhibited stronger activities than disaccharide $\mathbf{1 4}$ or tetrasaccharide $\mathbf{4}$. When the sugar group was varied, the free form of the hydroxyl group at C-2' reduced the activities $(\mathbf{2}<\mathbf{1 4} ; \mathbf{1 6}<\mathbf{9}, \mathbf{1 0} ; \mathbf{5}<\mathbf{1 7})$, and acetylation of the hydroxyl group at C-3' also decreased the activity $(3<13)$. Methylation of the hydroxyl group at $\mathrm{C}-3^{\prime}$, on the other hand, was not significant $(\mathbf{1 3} \approx \mathbf{1 5}, \mathbf{8} \approx \mathbf{1 0})$. Thus, the antiproliferative activity of cardenolides would seem to depend on hydrophilicity around C-3 of the aglycon moiety, the sugar-linkaged site.

Some changes of cellular shapes were microscopically observed in HT-1080 and A549 cells when the cells were treated with cardenolides. For example, echujin (15), which was isolated in a relatively high amount and showed the strongest antiproliferative activity, changed HT-1080 cells into stretching shapes at concentrations of $25-50 \mathrm{~nm}$ (Figs. $2 \mathrm{C}, \mathrm{D})$ and shrinking or multi-blebbing shapes at concentrations above $100 \mathrm{~nm}$ (Figs. 2E-H). In the case of A549 cells, stretching or shrinking shapes at the concentration of $50 \mathrm{~nm}$ (Fig. 2L) and shrinking or multi-blebbing shapes at concentrations above $100 \mathrm{~nm}$ (Figs. 2M-P) were also observed. These morphological changes are typical for apoptosis. ${ }^{22}$ Cardenolides were reported to induce DNA fragmentation in an androgen-independent human prostate adenocarcinoma cell line. ${ }^{23)}$ Thus, we examined whether cardenolides induced apoptosis in HT-1080 and A549 cells. As can be seen in Fig. 3, 15 induced ladder-like DNA fragmentation in HT-1080 cells at concentrations above $50 \mathrm{~nm}$ and in A549 cells at concentrations greater than $10 \mathrm{~nm}$ in concentration-dependent manners. These DNA fragmentations and characteristic morphological changes indicated that the antiproliferative activity of cardenolides is mediated through apoptosis. The water extract of Nerium oleander, Anvirzel ${ }^{\mathrm{TM}}$, which contains some cardenolides (e.g., oleandrin), is a clinical trial drug for cancer treatment in the USA. ${ }^{24)}$ The extract of $S$. juventas and its cardenolides which induced apoptosis in tumor cells thus seem to be desirable candidates for clinical drugs as well as tools for investigating the molecular mechanism of apoptosis.

Acknowledgement This work was supported in part by a Grant-in-Aid for International Scientific Research (No. 13576027) from the Ministry of Education, Culture, Sports, Science and Technology, Japan.

\section{REFERENCES}

1) Vo V. C., "Dictionary of Vietnamese Medicinal Plants," Medicine, Hochiminh City, 1996, pp. 537-538.

2) Nguyen V. D., Doan T. N., "Medicinal Plants in Viet Nam," World Health Organization Regional Office for Western Pacific, Manila, Institute of Materia Medica, Hanoi, Science and Technology, Hanoi, 1998, pp. $380-381$.

3) Do T. L., "Vietnamese Medicinal Plants," Medicine, Hanoi, 2001, pp. $836-837$.

4) Banskota A. H., Tezuka Y., Tran K. Q., Tanaka K., Saiki I., Kadota S., Chem. Pharm. Bull., 48, 496-504 (2000). See also references cited therein.

5) Tezuka Y., Stampoulis P., Banskota A. H., Awale S., Tran K. Q., Saiki I., Kadota S., Chem. Pharm. Bull., 48, 1711-1719 (2000). See also references cited therein.

6) Adnyana I K., Tezuka Y., Banskota A. H., Tran K. Q., Kadota S., J. Nat. Prod., 64, 360-363 (2001). See also references cited therein.

7) Tran Q. L., Adnyana I K., Tezuka Y., Nagaoka T., Tran Q. K., Kadota S., J. Nat. Prod., 64, 456-461 (2001). See also references cited therein.

8) Ueda J., Tezuka Y., Banskota A. H., Tran L. Q., Tran K. Q., Harimaya Y., Saiki I., Kadota S., Biol. Pharm. Bull., 25, 753-760 (2002).

9) Ueda J., Tezuka Y., Banskota A. H., Tran L. Q., Tran K. Q., Saiki I., Kadota S., J. Nat. Prod., submitted.

10) Fieser L. F., Fieser M., "Steroids," Chap. 20, Reinhold, New York, 1959 , pp. $727-809$

11) Marshall P. G., "Rodd's Chemistry of Carbon Compounds," 2nd ed., Vol. II-D, Chap. 17, ed. by Coffey S., Elsevier, Amsterdam, 1970, pp. $360-421$.

12) Singh B., Pastogi R. P., Phytochemistry, 9, 315-331 (1970).

13) Johansson S., Lindholm P., Gullbo J., Larsson R., Bohlin L., Claeson P., Anti-Cancer Drugs, 12, 475-483 (2001).

14) Rasheed S., Nelson-Rees W. A., Toth E. M., Arnstein P., Gardner M. 
B., Cancer, 33, 1027-1033 (1974).

15) Gey G. O., Coffman W. D., Kubicek M. T., Cancer Res., 12, 264-265 (1952).

16) Giard D. J., Aaronson S. A., Todaro G. J., Arnstein P., Kersey J. H., Dosik H., Parks W. P., J. Natl. Cancer Inst., 51, 1417-1423 (1973).

17) Lieber M., Smith B., Szakal A., Nelson-Rees W., Todaro G., Int. J. Cancer, 17, 62-70 (1976).

18) Ohnishi Y., Sakamoto T., Fujii H., Kimura F., Murata J., Tazawa K., Fujimaki M., Sato Y., Kondo M., Une Y., Uchino J., Saiki I., Tumor Biol., 18, 113-122 (1997).

19) Aptekman P. M., Lewis M. R., J. Immunol., 66, 361-364 (1951).
20) Hart I. R., Am. J. Pathol., 97, 587-600 (1979).

21) Rubinstein L. V., Shoemaker R. H., Paull K. D., Simon R. M., Tosini S., Skehan P., Scudiero D. A., Monks A., Boyd M. R., J. Natl. Cancer Inst., 82, 1113-1118 (1990).

22) Wyllie A. H., Kerr J. F. R., Currie A. R., Int. Rev. Cytol., 68, 251-306 (1980).

23) McConkey D. J., Lin Y., Nutt L. K., Ozel H. Z., Newman R. A., Cancer Res., 60, 3807-3812 (2000).

24) Pathak S., Multani A. S., Narayan S., Kumar V., Newman R. A., AntiCancer Drugs, 11, 455-463 (2000). 